Article

\title{
How Social Ties Influence Customers' Involvement and Online Purchase Intentions
}

\author{
Liang Ma*D, Xin Zhang, Xiaoyan Ding $\mathbb{D}$ and Gaoshan Wang \\ School of Management Science and Engineering, Shandong University of Finance and Economics, \\ Jinan 250014, China; Zhangxin@sdufe.edu.cn (X.Z.); Dingxiaoyan92@163.com (X.D.); \\ wanggs3506@126.com (G.W.) \\ * Correspondence: maliang1010@126.com
}

Received: 30 March 2020; Accepted: 20 October 2020; Published: 20 November 2020

\begin{abstract}
A major challenge confronting online retailers is that of stimulating consumer online purchase intention. Many studies have explored the factors that affect consumer purchase behavior; however, few have described the underlying mechanism that links the online shopping experience to social ties and the effect of their strength on purchase intentions. This study adapted the stimuli-organism-response (S-O-R) model to analyze the effects of the online shopping experience on customer involvement and online purchase intention under conditions of weak and strong social ties. Two quasi-experiments were conducted to test the research model and hypotheses. The results showed that online shopping experience had a positive effect on customer involvement, and this involvement in turn had a positive effect on online purchase intention in the strong-tie group and the weak-tie group. Cognitive and affective involvement played partial mediating roles between the online shopping experience and online purchase intention in the weak-ties group and full mediating roles in the strong-ties group. The effects of online shopping experience on customer involvement and online purchase intention differed between the two tie strength groups. The implications of these findings for researchers and practitioners are discussed.
\end{abstract}

Keywords: online shopping experience; cognitive involvement; affective involvement; tie strength; online purchase intention

\section{Introduction}

The development of the internet has led to a global boom in online shopping, especially in China. According to China Internet Network Information Center (CNNIC), as of June 2019, there were 639 million online shopping users in China [1]. To meet this demand, the number of online retailers also expanded dramatically. Competition among these retailers is fierce, and it is becoming more difficult to produce online purchase intention among consumers [2]. To prompt other consumers to make more online purchases, many retailers encourage those with whom they have a relationship to write online reviews and help others find good products and services. Although this measure is somewhat effective, it has some serious problems. For example, many members of the so-called Internet Water Army have accounts on e-commerce websites, and the reviews they produce may artificially inflate the value of a product. Untrustworthy reviews force consumers to spend additional time and energy in seeking the products they want [3]. Additionally, consumers often find contradictory reviews, and potential buyers may become too confused by this to make reliable decisions [4]. Online shopping would be improved if users were to be able to rely on the ties they have with their friends or on experienced shoppers to provide them with good information, as relationship strength is an important factor that drives trust and encourages purchases [5]. It is thus particularly urgent to investigate how relationship strength influences online purchase intention. 
A review of the literature on online shopping suggests that online shopping experience and customer involvement are important factors in determining how to improve online shopping intention [6]. A pleasant online shopping experience can often be quite effective in reducing consumer risk perception [7], and personal involvement is a strong indicator for product interest [8]. However, most studies have not examined the joint impact of the online shopping experience and consumer involvement on online shopping intention [9]. Customers differ in their online shopping expertise, and this can have significant effects on their shopping experience [8] and reduce their involvement. It should be noted that most previous work has investigated consumer involvement on a single dimension [5,8], but this is insufficient to describe the complexity of purchase decisions. This study also investigates the moderating role of tie strength [10]. Here, an example of a strong tie would be that to a close friend or family member with whom one is intimate, and a weak tie would be to an acquaintance with whom one does not feel emotionally close [11]. Prior research has found that the information and recommendations provided through strong ties has a greater effect on purchase intentions than that provided through weak ties [12]. However, it has also been noted that, for consumers at the initial shopping stage, recommendations arriving through weak ties may be more persuasive than those that come through strong ties, although the opposite is true at later stages [13]. Existing studies have examined the relationship between tie strength and purchase intention both directly and through a mediator, but the conclusions of this research are controversial, incomplete, and unsystematic $[14,15]$. In particular, the effects of relationship strength on purchase intention are more susceptible to moderating effects [13]. It remains unclear how tie strength influences customers' online shopping experience and their degree of involvement in relation to their online purchase intention. Analysis of this problem can help deepen our understanding of the mechanisms through which tie strength influences customers' involvement and online shopping intention. Online retailers can use this information to tailor the interactive features of their web content in response to consumers' unique tie strengths and specific involvement.

Drawing upon the stimuli-organism-response (S-O-R) model, this study examined the effects of the online shopping experience on consumer involvement and purchase intention in the context of different tie strengths. This study has the following contributions: an examination of how online shopping experience affects consumers' online shopping intention through their involvement and the discovery of the novel moderating variable of tie strength in the Chinese context. The paper is organized as follows: Section 2 provides the theoretical background and presents the hypotheses; Section 3 describes the research methods; it is followed by data analysis in Section 4; Section 5 discusses the research findings, implications, and limitations; and Section 6 gives the conclusions.

\section{Theoretical Background and Hypotheses}

\subsection{Stimuli-Organism-Response Model}

The S-O-R model posits that environmental and informational cues are stimuli that affect individuals' cognitive and affective reactions, which in turn affect behavior [10]. Stimuli can take many forms. Here, an online shopping experience is a stimulus that can affect or change an individual's internal and organic states [16]. An organism is understood as a cognitive or affective intermediary state that links a stimulus to an individual's response. This response incorporates psychological reactions that are manifest as specific attitudinal or behavioral changes. Using the S-O-R framework, this study adopted a theoretical model in which a stimulus $S$ referred to a consumer's experience with online shopping, organism $\mathrm{O}$ was the individual's intervening involvement in the relationship between stimulus and response, and response $\mathrm{R}$ denoted the individual's online purchase intention. The S-O- $\mathrm{R}$ model was used to examine whether stimulating factors, such as a good online shopping experience, positively affects organism factors, including consumer involvement, which can in turn promote a desired response—online purchases. 


\subsection{Online Shopping Experience and Customer Involvement}

This paper defines online shopping experience as a cognitive and affective state in a customer resulting from interactions with a shopping website [17]. A review of the literature showed that individuals with a great deal of experience were distinct from inexperienced ones in the quantity, content, and organization of their knowledge [18]. It has been shown that positive online shopping experiences are stimuli that enhance an individual's trust and increase their intention to make online purchases [16], promote satisfaction, and repurchase intention, and reduce complaints [19]. Although the consumer experience has received widespread investigation within the context of online shopping, an important aspect that has often been ignored by scholars is the relationship between this experience and a customer's direct involvement in shopping.

Involvement has been defined as the "perceived relevance of the object based on inherent needs, values, and interests" after exploring the enduring and intrinsic relevance of the object [20]. Through literature review, this paper divided customer involvement into two aspects: cognitive and affective involvement. Here, cognitive involvement relates to rational thinking and is induced by utilitarian or cognitive motives [21]. Affective involvement, by contrast, is associated with emotions and hedonic assessment and is induced by value-expressive or affective motives [8]. The customer experience can be conceptualized as a psychological construct with cognitive and affective aspects [22]. Customers with more online shopping experience often display additional skills and knowledge due to their frequent use of shopping websites and their services, and they can usually customize the impression of available information by filtering out irrelevant details, which enables them to become more absorbed in their interactions with the website (greater cognitive involvement). This allows them to be acutely involved in their own cognitive processing of information. Customers with more online shopping experience can promote self-gratification by gathering information more easily, which leads to increased pleasure and affinity (affective involvement). In light of this evidence, we hypothesize the following:

H1. Customers' online shopping experience has a positive effect on their cognitive involvement in the weakly tied group (H1a) and the strongly tied group (H1b).

H2. Customers' online shopping experience has a positive effect on their affective involvement in the weakly tied group $(\mathrm{H} 2 a)$ and the strongly tied group $(\mathrm{H} 2 b)$.

\subsection{Customer Involvement and Online Shopping Intention}

It is now considered imperative to assess customer involvement for the understanding and prediction of consumers' online shopping behavior $[23,24]$. Studies have shown that involvement with a website is positively related to attitudes towards it, which in turn influence consumer intention to make purchases from it [8]. It been shown that consumer cognitive states impact shopping outcomes [25]. Consumers who experience high cognitive involvement are more likely to obtain product information from the website. However, in low cognitive involvement with a website, consumers are unable to derive valuable product information, which may lead to reduced desire to purchase products. Thus, high cognitive involvement is more likely to lead to online purchase intention. Affective involvement describes heightened emotional feelings associated with the website and arises from feeling states [8]. Positive feeling states include happiness and satisfaction and may lead to higher purchase intentions at a given online store. However, negative feeling states, such as anger and dissatisfaction, may reduce the desire to purchase at that store. Huang [26] showed that affective and cognitive involvement influence purchase intention. In light of this, we hypothesize the following:

H3. Customers' cognitive involvement has a positive effect on their online shopping intention in the weakly tied group $(\mathrm{H} 3 \mathrm{a})$ and the strongly tied group $(\mathrm{H} 3 b)$. 
H4. Customers' affective involvement has a positive effect on their online shopping intention in the weakly tied group ( $\mathrm{H} 4 \mathrm{a})$ and the strongly tied group $(\mathrm{H} 4 \mathrm{~b})$.

\subsection{Moderating Role of Tie Strength}

A tie refers to the subjective experience of intimacy, emotional affinity, and psychological bonding with another person [27]. Greater tie strengths increase trust in others, creating relationships of closeness, intimacy, support, and association $[10,28]$. The most common means of measuring tie strength is determinations of the closeness of a given relationship; thus, close friends are defined as having strong ties, and the ties to acquaintances or friends of friends are assigned weak values [11,29]. For this reason, we treated tie strength and relationship closeness interchangeably. Previous research has confirmed that social ties affect users' attitudes, emotions, and behavior $[12,14]$. Source credibility theory suggests that people are most easily persuaded by a source that they consider to be credible [30]. Sources with strong ties are considered to be more credible and trustworthy than those with weak ones. Customers' affective and cognitive involvement may be higher in relation to information that arrives through stronger ties because their enhanced source credibility and persuasiveness are more convincing. Information and recommendations provided by contacts with strong ties have a greater effect on purchase intentions than those from weak-tie contacts [12], due to their credibility in particular. Accordingly, we propose the following hypothesis:

H5a. The relationship between online shopping experience and customers' cognitive involvement is stronger for the strongly tied group than for the weakly tied group.

$\mathbf{H} 5 \mathbf{b}$. The relationship between online shopping experience and customers' affective involvement is stronger for the strongly tied group than for the weakly tied group.

H5c. The relationship between customers' cognitive involvement and their online shopping intention is stronger for the strongly tied group than for the weakly tied group.

H5d. The relationship between customers' affective involvement and their online shopping intention is stronger for the strongly tied group than for the weakly tied group.

Based on the stimuli-organism-response model and the discussion above, this study proposes an integrated model as shown in Figure 1.

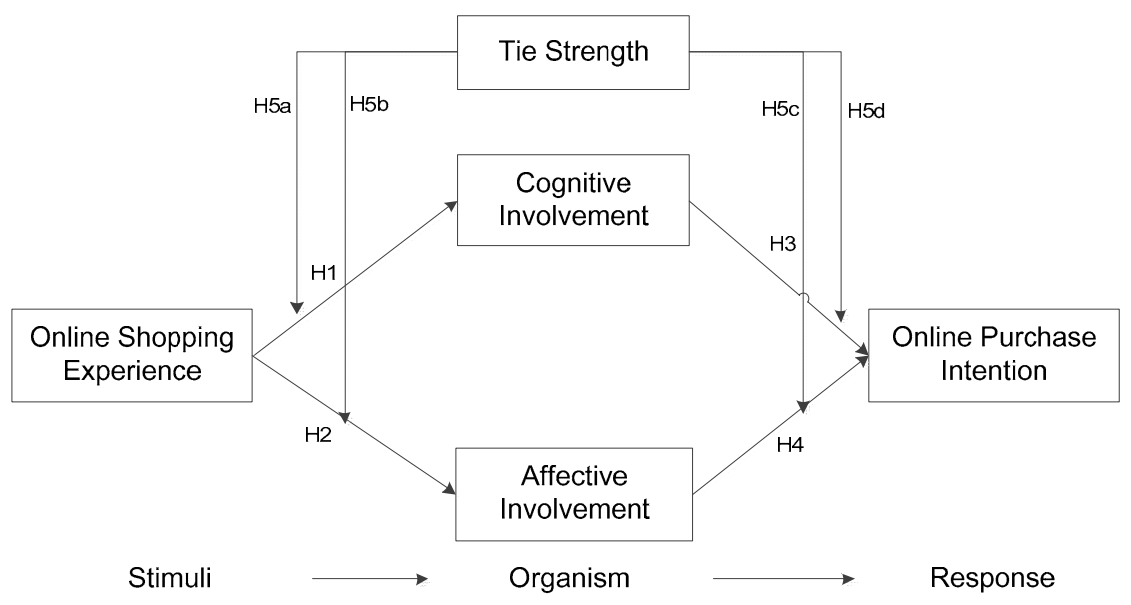

Figure 1. Research model.

\section{Methodology}

Using a professional questionnaire platform in China, we recruited 232 volunteers who reported having shopped online to participate in our Quasi-experiments 1 and 2. Following [11,29,31], 
we used the closeness of a relationship to measure tie strength, where close friends have strong ties, and acquaintances have weak ones. Strong ties in this study were represented by relationships between customers and their friends, and weak ties were represented by the relationship between customers and the author of an unbiased online review.

First, we assumed that customers wished to make an online purchase of a mobile phone from a well-known brand. We randomly selected a vendor from among the top five vendors by sales on the Taobao shopping platform, and an unbiased online review of the product was selected for the weak-tie scenario [28]. We asked the 232 respondents to read the review and complete a questionnaire. This was Quasi-experiment 1.

Second, we designed in the questionnaire that a friend of the participant, using WeChat or QQ, had given the same review to the same circle of friends that the participant is part of and that the respondent had seen this comment. This was the strong-tie scenario because of the relationship between the message sender and the participant [31]. We asked the same respondents to complete a questionnaire. This was Quasi-experiment 2.

\subsection{Questionnaire Measures}

In the quasi-experiments, we used a questionnaire to establish customers' online shopping experience, involvement, and online purchase intention. The questionnaire items were adapted from the literature. The items and factor loadings are given in Table 1 . The cognitive- and affective-involvement scales were adapted from [8,32]. Three items measuring online shopping experience were taken from [33]. Four items on purchase intention were revised from [34]. All items were measured on a 7-point Likert scale, ranging from 1 (strongly disagree or unlikely) to 7 (strongly agree or likely).

Table 1. Construct measuring.

\begin{tabular}{|c|c|c|c|c|}
\hline Factor & Measure Items & $\begin{array}{l}\text { Factor Loadings } \\
\text { (Weak Group) }\end{array}$ & $\begin{array}{l}\text { Factor Loadings } \\
\text { (Strong Group) }\end{array}$ & Source \\
\hline \multirow{4}{*}{$\begin{array}{c}\text { Cognitive } \\
\text { Involvement }(\mathrm{CI})\end{array}$} & $\begin{array}{l}\text { CI1. The product is unimportant } \\
\text { (1)/important (7) }\end{array}$ & 0.865 & 0.849 & \multirow{4}{*}{ [8] } \\
\hline & $\begin{array}{l}\text { CI2. The product is irrelevant } \\
\text { (1)/relevant (7) }\end{array}$ & 0.800 & 0.858 & \\
\hline & $\begin{array}{l}\text { CI3. The product is worthless } \\
\text { (1)/valuable (7) }\end{array}$ & 0.855 & 0.885 & \\
\hline & $\begin{array}{l}\text { CI4. The product is not needed } \\
\text { (1)/needed (7) }\end{array}$ & 0.868 & 0.826 & \\
\hline \multirow{4}{*}{$\begin{array}{c}\text { Affective } \\
\text { Involvement (AI) }\end{array}$} & $\begin{array}{l}\text { AI1. The product expresses/does } \\
\text { not express one's personality }\end{array}$ & 0.860 & 0.868 & \multirow{4}{*}{ [8] } \\
\hline & $\begin{array}{l}\text { AI2. The product is based on a lot } \\
\text { of/little feeling }\end{array}$ & 0.875 & 0.894 & \\
\hline & $\begin{array}{l}\text { AI3. The product is unappealing } \\
\text { (1)/appealing ( } 7)\end{array}$ & 0.899 & 0.878 & \\
\hline & $\begin{array}{l}\text { AI4. The product is mundane } \\
(1) / \text { fascinating }(7)\end{array}$ & 0.861 & 0.860 & \\
\hline \multirow{3}{*}{$\begin{array}{c}\text { Shopping } \\
\text { Experience (SE) }\end{array}$} & $\begin{array}{l}\text { SE1. I have shopped online } \\
\text { extensively }\end{array}$ & 0.811 & 0.893 & \multirow{3}{*}{ [33] } \\
\hline & $\begin{array}{l}\text { SE2. I have used the internet to } \\
\text { shop for a long time }\end{array}$ & 0.911 & 0.921 & \\
\hline & SE3. I shop online frequently & 0.853 & 0.908 & \\
\hline
\end{tabular}


Table 1. Cont.

\begin{tabular}{|c|c|c|c|c|}
\hline Factor & Measure Items & $\begin{array}{l}\text { Factor Loadings } \\
\text { (Weak Group) }\end{array}$ & $\begin{array}{l}\text { Factor Loadings } \\
\text { (Strong Group) }\end{array}$ & Source \\
\hline \multirow{4}{*}{$\begin{array}{l}\text { Purchase Intention } \\
\text { (PI) }\end{array}$} & $\begin{array}{l}\text { PI1. I would consider buying this } \\
\text { product. }\end{array}$ & 0.881 & 0.865 & \multirow{4}{*}{ [34] } \\
\hline & $\begin{array}{l}\text { PI2. It is possible that I would buy } \\
\text { this product. }\end{array}$ & 0.873 & 0.864 & \\
\hline & $\begin{array}{l}\text { PI3. I will purchase (brand) the } \\
\text { next time I need a (product). }\end{array}$ & 0.876 & 0.885 & \\
\hline & $\begin{array}{l}\text { PI4. If I am in need, I would buy } \\
\text { this (product) }\end{array}$ & 0.856 & 0.888 & \\
\hline
\end{tabular}

\subsection{Data Collection}

A pretest was conducted using two professors and five graduate students to assess the logical consistency, ease of understanding, and contextual relevance of the questionnaire. During the quasi-experiments, we collected demographic information, including gender, age, education, income, and occupation. Respondent characteristics are presented in Table 2.

Table 2. Descriptive statistics of respondent characteristics.

\begin{tabular}{cccc}
\hline & Demographic Variable & Sample Size & $\%$ \\
\hline \multirow{2}{*}{ Gender } & Male & 118 & 50.86 \\
& Female & 114 & 49.14 \\
\hline \multirow{2}{*}{ Age } & $\leq 20$ years old & 2 & 0.86 \\
& $21-30$ years old & 95 & 40.95 \\
& $31-40$ years old & 101 & 43.53 \\
Education & $>41$ years old & 34 & 14.66 \\
& Senior middle school or below & 11 & 4.74 \\
& Junior college & 33 & 14.22 \\
& Bachelor's degree & 173 & 74.57 \\
Monthly personal & Master's degree or above & 15 & 6.47 \\
income (RMB) & $\leq 3000$ & 30 & 12.93 \\
& 3001-5000 & 64 & 27.59 \\
& $5001-8000$ & 76 & 32.76 \\
& 8001-15,000 & 45 & 19.40 \\
& $>15,000$ & 17 & 7.33 \\
\hline \multirow{3}{*}{ Occupation } & Student & 11 & 4.74 \\
& Enterprise staff & 171 & 73.71 \\
& Government employee & 36 & 15.52 \\
& Self-employed entrepreneur & 14 & 6.03 \\
\hline
\end{tabular}

\section{Data Analysis and Results}

\subsection{Measurement Model Validation}

The validation of the measurement model was done using reliability and discriminant validity. Reliability was measured by Cronbach's alpha, composite reliability (CR), and average variance extracted (AVE). Acceptable values were often taken to be $>0.7$ for Cronbach's alpha, $>0.7$ for CR, and $>0.5$ for AVE [35]. The results for the weak-tie quasi-experiment are presented in Table 3 . Cronbach's alpha ranged from 0.823 to 0.897 , CR was 0.894 to 0.928 , and AVE was 0.718 to 0.764 . Thus, the reliability of the scales was considered acceptable. We also tested discriminant validity. The square root for each factor's AVE value was larger than its corresponding correlation coefficient with other factors, indicating adequate discriminant validity. The results for the strong-tie quasi-experiment 
are shown in Table 4. The validation values for this group were 0.877 to 0.899 for Cronbach's alpha, 0.916 to 0.933 for CR, and 731 to 0.823 for AVE. Thus, the reliability of the scales was acceptable here as well. The square root for each factor's AVE was larger than its corresponding correlation coefficients with other factors, indicating adequate discriminant validity.

Table 3. Reliability and validity (weak ties).

\begin{tabular}{cccccccccc}
\hline Items & Mean & SD & $\begin{array}{c}\text { Cronbach's } \\
\text { Alpha }\end{array}$ & $\begin{array}{c}\text { Composite } \\
\text { Reliability }\end{array}$ & AVE & AI & CI & PI & SE \\
\hline AI & 5.386 & 1.197 & 0.897 & 0.928 & 0.764 & 0.874 & & & \\
CI & 5.581 & 1.177 & 0.869 & 0.910 & 0.718 & 0.701 & 0.847 & & \\
PI & 5.575 & 1.140 & 0.895 & 0.927 & 0.760 & 0.690 & 0.734 & 0.872 & \\
SE & 5.983 & 1.121 & 0.823 & 0.894 & 0.738 & 0.505 & 0.592 & 0.565 & 0.859 \\
\hline
\end{tabular}

Note: SE: shopping experience; CI: cognitive involvement; AI: affective involvement; PI: purchase intention.

Table 4. Reliability and validity (strong ties).

\begin{tabular}{cccccccccc}
\hline Items & Mean & SD & $\begin{array}{c}\text { Cronbach's } \\
\text { Alpha }\end{array}$ & $\begin{array}{c}\text { Composite } \\
\text { Reliability }\end{array}$ & AVE & AI & CI & PI & SE \\
\hline AI & 5.434 & 1.195 & 0.898 & 0.929 & 0.766 & 0.875 & & & \\
CI & 5.512 & 1.188 & 0.877 & 0.916 & 0.731 & 0.779 & 0.855 & & \\
PI & 5.539 & 1.188 & 0.899 & 0.929 & 0.767 & 0.767 & 0.758 & 0.876 & \\
SE & 5.971 & 1.138 & 0.893 & 0.933 & 0.823 & 0.557 & 0.564 & 0.515 & 0.907 \\
\hline
\end{tabular}

Note: SE: shopping experience; CI: cognitive involvement; AI: affective involvement; PI: purchase intention.

Because all constructs were measured subjectively in relation to the same sources at the same time, this study carried on an additional step to check a potential common method bias. We employed the Harman single-factor test and an exploratory factor analysis using SPSS 20.0. No single factor appeared in the statistical results because the variance in the first factor was less than the recommended threshold of 50\%, so common method bias was not a serious concern in this study [36].

\subsection{Structural Model Assessment}

Smart PLS 2.0 was used to analyze the data and check assumptions. A second generation multivariate technique, Smart PLS is able to simultaneously assess a measurement model and a structural model [6]. Relative to covariance-based structural equation modeling, PLS allows a relatively small sample size to be used, with no restriction on normal distribution, and it is more appropriate for exploratory analysis and handling formative constructs [37,38], making it suitable for this study.

The results of Quasi-experiment 1 (weak ties) are shown in Figure 2. Online shopping experience had a positive effect on cognitive involvement $(\beta=0.592, t=19.259, p<0.05$, one-tailed $)$ and affective involvement ( $\beta=0.505, t=15.134, p<0.05$, one-tailed). Thus, hypotheses H1a and H2a were supported. This means that shoppers' cognitive and affective involvement increase in an online shopping experience in a weak-tie scenario. Both cognitive $(\beta=0.561, t=11.392, p<0.05$, one-tailed) and affective ( $\beta=0.341, t=6.899, p<0.05$, one-tailed) involvement had a positive effect on users' online purchase intention in the weak-tie scenario. Thus, H3a and H4a were supported. The greater the cognitive and affective involvement of the consumer, the more likely they were to make an online purchase.

The results of Quasi-experiment 2 (strong ties) are shown in Figure 3. Online shopping experience had a positive effect on cognitive involvement $(\beta=0.564, t=17.233, p<0.05$, one-tailed) and affective involvement $(\beta=0.557, t=15.970, p<0.05$, one-tailed); thus, hypotheses $\mathrm{H} 1 \mathrm{~b}$ and $\mathrm{H} 2 \mathrm{~b}$ were supported. This means that consumers' cognitive and affective involvement increase in an online shopping experience in a strong-tie scenario. Additionally, cognitive involvement $(\beta=0.422, t=12.723, p<0.05$, one-tailed) and affective involvement $(\beta=0.496, t=14.729, p<0.05$, one-tailed) had a positive effect on shoppers' online purchase intention; thus, $\mathrm{H} 3 \mathrm{~b}$ and $\mathrm{H} 4 \mathrm{~b}$ were supported. This means that 
the greater the cognitive and affective involvement, the stronger the online purchase intention in a strong-ties scenario.

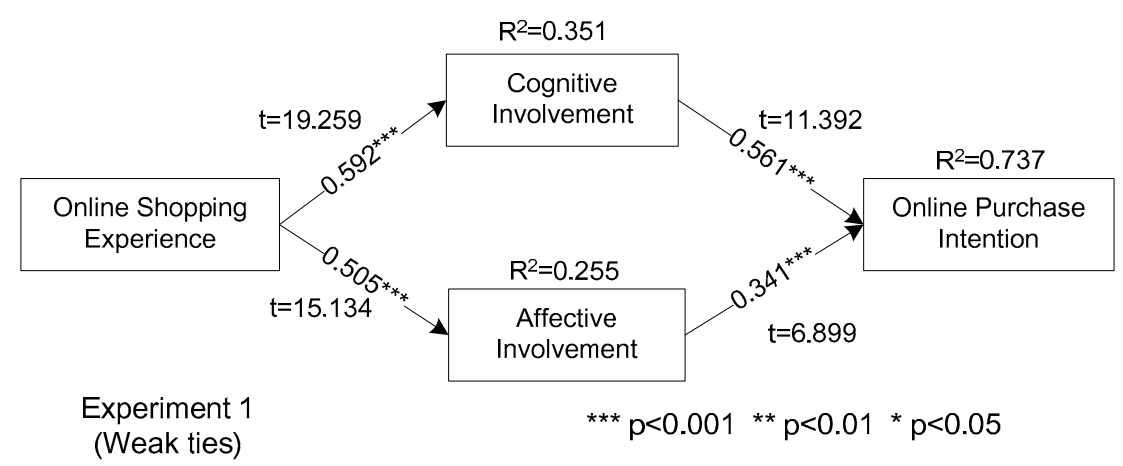

Figure 2. Results of structure model analysis (weak ties).

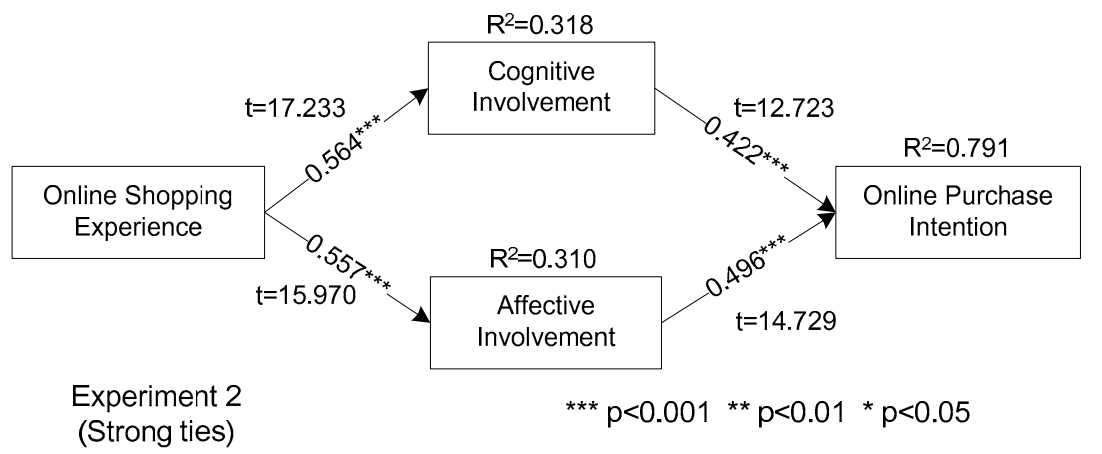

Figure 3. Results of structure model analysis (strong ties).

\subsection{Mediating Effect}

The widely accepted bootstrap method was used to test the mediating effect of customer involvement. SPSS 20.0 and the PROCESS SPSS macro developed by Hayes were used to test mediation [39]. This study used both the bias-corrected method and the percentile method to test the mediating effect, and the confidence level for the confidence intervals was $95 \%$. It has been suggested that when the confidence interval of the indirect effect, as measured by the bias-corrected method or the percentile method, does not include zero, then a mediating effect is indicated [39]. Partially mediated effects are present when the confidence intervals for both the indirect and direct effects do not include zero. A fully mediated effect is present when the confidence interval of the indirect effect does not include zero, and the confidence interval of the direct effect does include zero, as shown in Table 5.

In the weak-tie group, all of the $t$ values were greater than 1.96, and the confidence intervals of the indirect and direct effects did not include zero. Thus, cognitive involvement and affective involvement acted as partial mediating effects between customers' shopping experience and online purchase intention. This implies that customers' shopping experience has a positive influence on online purchase intention through cognitive and affective involvement. In the strong-tie group, however, it was interesting to note that the confidence interval of the indirect effect did not include zero, but the confidence interval of the direct effect did. Thus, consumers' cognitive and affective involvement acted as full mediators between online shopping experience and online purchase intention. This means that with a strong-tie recommendation, customers' shopping experience directly affects their online purchase intention through cognitive and affective involvement. 
Table 5. Results of mediating effects.

\begin{tabular}{|c|c|c|c|c|c|c|c|c|c|}
\hline \multirow{3}{*}{$\begin{array}{l}\mathbf{M} /(\mathbf{I V}) /(\mathbf{D V}) \\
\begin{array}{l}\mathrm{CI} /(\mathrm{SE}) /(\mathrm{PI}) \\
\text { (Weak ties) }\end{array}\end{array}$} & \multirow{3}{*}{$\begin{array}{c}\text { Items } \\
\text { Direct effect } \\
\text { Indirect effect }\end{array}$} & \multirow{3}{*}{$\begin{array}{l}\text { Effect } \\
0.118 \\
0.447\end{array}$} & \multicolumn{2}{|c|}{ Coefficient } & \multirow{2}{*}{\multicolumn{2}{|c|}{$\begin{array}{c}\text { Bias-Corrected } \\
95 \% \mathrm{CI}\end{array}$}} & \multirow{2}{*}{\multicolumn{2}{|c|}{$\begin{array}{c}\text { Percentile } \\
95 \% \text { CI }\end{array}$}} & \multirow{3}{*}{$\begin{array}{r}\begin{array}{r}\text { Mediatior } \\
\text { Existence }\end{array} \\
\text { Partial }\end{array}$} \\
\hline & & & \multirow{2}{*}{$\begin{array}{c}\text { SE } \\
0.045 \\
0.066\end{array}$} & \multirow{2}{*}{$\begin{array}{c}\mathbf{T} \\
2.625 \\
6.773\end{array}$} & & & & & \\
\hline & & & & & $\begin{array}{l}0.029 \\
0.325\end{array}$ & $\begin{array}{l}0.206 \\
0.589\end{array}$ & $\begin{array}{l}0.029 \\
0.314\end{array}$ & $\begin{array}{l}0.206 \\
0.577\end{array}$ & \\
\hline $\begin{array}{c}\mathrm{AI} /(\mathrm{SE}) /(\mathrm{PI}) \\
\text { (Weak ties) }\end{array}$ & $\begin{array}{c}\text { Direct effect } \\
\text { Indirect effect }\end{array}$ & $\begin{array}{l}0.232 \\
0.333\end{array}$ & $\begin{array}{l}0.044 \\
0.049\end{array}$ & $\begin{array}{l}5.218 \\
6.796\end{array}$ & $\begin{array}{l}0.144 \\
0.244\end{array}$ & $\begin{array}{l}0.319 \\
0.432\end{array}$ & $\begin{array}{l}0.144 \\
0.237\end{array}$ & $\begin{array}{l}0.319 \\
0.425\end{array}$ & Partial \\
\hline $\begin{array}{l}\mathrm{CI} /(\mathrm{SE}) /(\mathrm{PI}) \\
\text { (Strong ties) }\end{array}$ & $\begin{array}{l}\text { Direct effect } \\
\text { Indirect effect }\end{array}$ & $\begin{array}{l}0.053 \\
0.462\end{array}$ & $\begin{array}{l}0.041 \\
0.058\end{array}$ & $\begin{array}{l}1.290 \\
7.966\end{array}$ & $\begin{array}{c}-0.028 \\
0.361\end{array}$ & $\begin{array}{l}0.134 \\
0.587\end{array}$ & $\begin{array}{l}-0.028 \\
0.346\end{array}$ & $\begin{array}{l}0.134 \\
0.575\end{array}$ & Full \\
\hline $\begin{array}{l}\mathrm{AI} /(\mathrm{SE}) /(\mathrm{PI}) \\
\text { (Strong ties) }\end{array}$ & $\begin{array}{l}\text { Direct effect } \\
\text { Indirect effect }\end{array}$ & $\begin{array}{l}0.053 \\
0.462\end{array}$ & $\begin{array}{l}0.040 \\
0.055\end{array}$ & $\begin{array}{l}1.332 \\
8.400\end{array}$ & $\begin{array}{c}-0.025 \\
0.361\end{array}$ & $\begin{array}{l}0.131 \\
0.580\end{array}$ & $\begin{array}{l}-0.025 \\
0.346\end{array}$ & $\begin{array}{l}0.131 \\
0.557\end{array}$ & Full \\
\hline
\end{tabular}

\subsection{Moderating Effect}

Using the approach proposed by [40], this study tested the moderating effect of tie strength. Table 6 shows that tie strength positively moderated the relationship between online shopping experience and cognitive involvement. Thus, hypothesis H5a was supported. This implies that customer cognitive involvement increased more dramatically in the strong-tie group than in the weak-tie group with the increases of online shopping experience. Tie strength negatively moderated the relationship between online shopping experience and affective involvement. Thus, $\mathrm{H} 5 \mathrm{~b}$ was not supported. It is interesting to note that for increases in shopping experience, a customer's affective involvement increased more dramatically in the weak-tie group than in the strong-tie group. That is, the effects of strong ties were not always stronger than those of weak ties. This supports the results of [10], who held that weak ties were more influential in some conditions. Tie strength positively moderated the relationship between cognitive involvement and online shopping intention. Thus, hypothesis $\mathrm{H} 5 \mathrm{c}$ was supported. Customer purchase intention increased significantly more in the strong-tie group than in the weak-tie group with increases in cognitive involvement. Tie strength negatively moderated the relationship between affective involvement and online shopping intention. Thus, H5d was not supported. Customer purchase intention increased more in the weak-tie group than in the strong-tie group with increases in affective involvement. This implies that weak ties are more influential in determining buying intention with increases in affective involvement.

$$
\begin{gathered}
S_{\text {pooled }}=\sqrt{\left\{\left[\left(N_{1}-1\right) /\left(N_{1}+N_{2}-2\right)\right] \times S E_{1}^{2}+\left[\left(N_{2}-1\right) /\left(N_{1}+N_{2}-2\right)\right] \times S E_{2}^{2}\right\}} \\
t=\left(P C_{1}-P C_{2}\right) /\left[S_{\text {Pooled }} \times \sqrt{\left.\left(1 / N_{1}+1 / N_{2}\right)\right]}\right.
\end{gathered}
$$

Table 6. Comparison between strong ties and weak ties.

\begin{tabular}{cccccc}
\hline Hypothesis & $\begin{array}{c}\text { Weak Ties } \\
\text { (Group 1) }\end{array}$ & $\begin{array}{c}\text { Strong Ties } \\
\text { (Group 2) }\end{array}$ & $\boldsymbol{\Delta} \boldsymbol{\beta}$ & $\mathbf{T}$ & Hypothesis Support \\
\hline $\mathrm{SE}->\mathrm{CI}$ & $0.564^{* * *}$ & $0.592^{* * *}$ & 0.028 & 9.600 & H5a is supported $(\mathrm{S}>\mathrm{W})$ \\
\hline $\mathrm{SE}->\mathrm{AI}$ & $0.557^{* * *}$ & $0.505^{* * *}$ & 0.052 & 16.431 & H5b is not supported $(\mathrm{S}<\mathrm{W})$ \\
\hline $\mathrm{CI}->\mathrm{PI}$ & $0.422^{* * *}$ & $0.561^{* * *}$ & 0.139 & 35.700 & H5c is supported $(\mathrm{S}>\mathrm{W})$ \\
\hline $\mathrm{AI}->\mathrm{PI}$ & $0.496^{* * *}$ & $0.341^{* * *}$ & 0.155 & 39.456 & H5d is not supported $(\mathrm{S}<\mathrm{W})$ \\
\hline \multicolumn{5}{c}{ Note: ${ }^{* * *} p<0.001}$.
\end{tabular}

where $\mathrm{S}_{\text {pooled }}$ is the pooled estimator for the variance;

$\mathrm{t}$ is the $\mathrm{t}$-statistic with $\mathrm{N} 1+\mathrm{N} 2-2$ degrees of freedom;

$N_{\mathrm{i}}$ is the sample size of dataset for group $i$;

$S E_{\mathrm{i}}$ is the standard error of path in structural model of group $i$;

$P C_{\mathrm{i}}$ is the path coefficient in structural model of group $i$. 


\section{Discussion}

\subsection{Key Findings}

This study analyzed the effects of online shopping experience on customer involvement and online purchase intention in conditions of different social tie strengths. A two-part quasi-experiment was conducted to test the model and hypotheses. The results produced the following key findings.

In the strong- and weak-tie groups, online shopping experience had a positive effect on customer involvement, and customer involvement had a positive effect on online purchase intention. Increased online shopping experience led to more cognitive and affective involvement, which formed the basis of online purchase intention. McClure and Seock [41] also indicated that brand familiarity had significant effects on consumer involvement with a brand, which in turn influences future purchase intention for that brand. In addition, cognitive and affective involvement had a partial mediator between online shopping experience and online purchase intention in the weak-ties group, and it had a full mediator role in the strong-ties group. Earlier work found that the online shopping experience stimulated online purchase intention through trust [16]. This study takes a further step and finds that online shopping experience may also affect online purchase intention through cognitive and affective involvement.

The effects of online shopping experience on customer involvement and online purchase intention were different under different tie strengths. In the case of increased online shopping experience, cognitive involvement increased more dramatically in the strong-tie group, and affective involvement increased more in the weak-tie group. Furthermore, purchase intention increased more in the strong-tie group with greater cognitive involvement, and purchase intention was greater for weak ties with increased affective involvement. An earlier study found that the information and recommendations provided by strong-tie contacts had a greater effect on purchase intention than those for weak-tie contacts [12]. This study supported that perspective by indicating that in relation to cognitive involvement, the recommendations that arrived through strong ties were more persuasive than those coming through weak ties, but recommendations from weak ties were more persuasive than those from strong ties in affective involvement. Furthermore, recommendations from strong ties were more persuasive than those from weak ties for online purchase intentions at the same level of cognitive involvement, and recommendations from weak ties were more persuasive than those from strong ties for online purchase intentions at the same level of affective involvement.

\subsection{Theoretical Implications}

This paper contributes to the online shopping literature by examining how the online shopping experience affects shopping intention through the mediating role of involvement. Although existing research focuses on online shopping to a greater degree [19,33], it largely ignores the important mediating role of shopper involvement. This study divided customer involvement into two dimensions, cognitive and affective. Using this classification, it reveals the process of consumer involvement in more detail, and at the same time, it provides a reference and basis for follow-up research. It was found that cognitive and affective involvement played a different role for online shopping experience and online purchase intention in the weak-tie group and strong-tie group. Specifically, cognitive and affective involvement played a partial mediator role between online shopping experience and online purchase intention in the weak-tie group and a full mediator role in the strong-tie group. These results deepen our understanding of the mediating process that describes how the online shopping experience affects online purchase intention in the context of online shopping.

This study provides an expansion of the online shopping literature by investigating boundary conditions, namely tie strength, in a Chinese context. Prior research has generally found that the information and word of mouth provided by contacts with strong ties have a greater effect on purchase intentions [42], but the applicability of these conclusions among Chinese online consumers was not known. This study investigated the underlying effects of social ties in the mix of well-known drivers of online shopping intentions and found that these mechanisms were not necessarily applicable to the 
Chinese context. Unlike the findings of prior research, unsupported hypotheses suggested that word of mouth from weak ties was more persuasive for affective involvement, and this had a stronger influence on purchase intentions in relation to those ties. However, the supported hypotheses suggested that word of mouth from strong ties were more persuasive for cognitive involvement, and this had a stronger influence on purchase intentions in that case. Using classification practices and a detailed research approach, this study helped develop a more comprehensive understanding of how different tie strengths affect different involvements and online shopping intention. From a theoretical viewpoint, this study found that tie strength is a novel moderator among Chinese online consumers, and this forms a contribution to tie strength theory, and the research framework of this study provides a foundation and reference for follow-up research.

\subsection{Practical Implications}

This research provides insights for online retailers and operators, who could benefit by recognizing that online purchase intention is affected by shopping experience and cognitive involvement in addition to affective involvement. Our findings show that consumers' cognitive and affective involvement has a partially mediating role between online shopping experience and online purchase intention in the weak-ties group and a fully mediating role in the strong-ties group. This implies that online shopping retailers should pay more attention to consumers with more online shopping experience and adopt measures that increase their cognitive and affective involvement. For example, it would be wise to add live video and coupon distribution to increase interaction with consumers, which would further increase consumers' cognitive and affective involvement. To involve consumers more easily, the shopping interface should be simple and elegant, different shopping sections can be set up to display specific types of goods, and it should replicate the characteristics of a shop if possible. For online shopping operators, consumers can be ranked according to their level of expertise and can be granted different privileges to stimulate online shopping.

Online shopping retailers should consider also to seek to balance the effects of different tie strengths on online purchase intention. This study indicates that for weak ties, online shopping experience is more likely to affect online purchase intention through affective involvement, but for strong ties, online shopping experience is more likely to affect online purchase intention through cognitive involvement. Thus, online retailers may wish to take different measures to compensate for different tie strengths and involvement dimensions. For example, in weak-tie transactions, online retailers should pay more attention to consumer affective involvement, such as emotions and hedonic assessment in the shopping process. However, in strong-tie transactions, cognitive involvement is more important. Online retailers should pay closer attention to consumers' rational thinking and utilitarian or cognitive motives in the shopping. More importantly, online shopping platforms and retailers can consider the integration of their online presence and social platforms. In this way, when consumers shop online, they can view the shopping experiences of their friends, and this can produce strong ties and desirable stimulus.

\subsection{Limitations and Future Research}

The study employed a quasi-experimental approach in which we created two tie-strength scenarios and asked respondents to complete questionnaires in relation to online shopping in the context of each scenario. The findings of this study are significant and add to the body of knowledge on involvement and tie strength, but it is not without limitations. First, our results may be limited due to our focus on a single, binary tie-strength setting and by the method of data collection. Random samples are difficult to obtain for a study like this, and subject recruitment may have created bias in the study results. Second, the study was conducted in China, a country with a strong culture of guanxi [43]. Thus, the universality of the research conclusions needs further verification. It would be interesting to determine whether our findings would mirror those in Western countries. Third, this study focused on the effects of the 
online shopping experience on customer involvement and online purchase intention in the context of different tie strengths and did not consider the effects of other factors, such as product type.

\section{Conclusions}

While many prior studies on online shopping have examined the effects of involvement and tie strength $[8,9,23,41,42]$, this study goes beyond these studies by also considering the mediating role of involvement and the moderating role of tie strength in affecting consumers' online purchase intention. Dividing customer involvement into cognitive and affective involvement, this study examined the mediation effects between online shopping experience and online purchase intention in the context of weak and strong social ties. Quasi-experiments were conducted to test the research model and hypotheses. The results showed that cognitive involvement and affective involvement played partial mediator roles for online shopping experience and online purchase intention in the weak-ties group and full mediator roles in the strong-ties group. More importantly, the effects of online shopping experience on customer involvement and online purchase intention differed in the two tie strength groups.

Our model contributes to the online shopping literature by examining how the online shopping experience affects shopping intention through the mediating role of involvement. It also augments the existing online shopping literature by investigating boundary conditions, such as tie strength, in a Chinese context. This study provides practical implications with regard to increases in consumer involvement and on how to improve consumers' online shopping intention in different scenarios of tie strength. The findings suggest ways in which consumer involvement and tie strength can be integrated to enhance customer desire to make an online purchase. The current study was limited by data collection and the universality of its research conclusions, and it did not consider the effects of other factors, such as product type. Future studies could address product type or other factors and determine their effects on online shopping intention.

Author Contributions: X.Z. and G.W. conceptualization and designed the work. L.M. was accountable for conducting research and drafting the manuscript. X.D. was responsible for statistical analysis. All authors have read and agreed to the published version of the manuscript.

Funding: This research was funded by National Social Science Foundation of China grant number 18BGL263.

Acknowledgments: I would like to gratefully acknowledge the support of the Editorial Technical Team for setting these guidelines.

Conflicts of Interest: The authors declare no conflict of interest.

\section{References}

1. CNNIC. August 2019. Forty-Four Statistical Report on the Development of China Internet Network. Available online: http://www.cnnic.net.cn (accessed on 10 October 2019).

2. Dabrynin, H.; Zhang, J. The investigation of the online customer experience and perceived risk on purchase intention in China. J. Mark. Dev. Compet. 2019, 13, 16-30.

3. Fogel, J.; Zachariah, S. Intentions to Use the Yelp Review Website and Purchase Behavior after Reading Reviews. J. Theor. Appl. Electron. Commer. Res. 2017, 12, 53-67. [CrossRef]

4. Nakayama, M.; Wan, Y. Exploratory Study on Anchoring: Fake Vote Counts in Consumer Reviews Affect Judgments of Information Quality. J. Theor. Appl. Electron. Commer. Res. 2017, 12, 1-20. [CrossRef]

5. Safari, A. Customers' International Online Trust-Insights from Focus Group Interviews. J. Theor. Appl. Electron. Commer. Res. 2012, 7, 13-14. [CrossRef]

6. Spillinger, A.; Parush, A. The Impact of Testimonials on Purchase Intentions in a Mock E-commerce Web Site. J. Theor. Appl. Electron. Commer. Res. 2012, 7, 9-10. [CrossRef]

7. Shi, S.; Wang, Y.; Chen, X.; Zhang, Q. Conceptualization of omnichannel customer experience and its impact on shopping intention: A mixed-method approach. Int. J. Inf. Manag. 2020, 50, 325-336. [CrossRef]

8. Jiang, Z.; Chan, J.; Tan, B.C.; Chua, W.S. Effects of interactivity on website involvement and purchase intention. J. Assoc. Inf. Syst. 2010, 11, 34-59. [CrossRef] 
9. Liu, Q.; Zhang, X.; Huang, S.; Zhang, L.; Zhao, Y. Exploring Consumers' Buying Behavior in a Large Online Promotion Activity: The Role of Psychological Distance and Involvement. J. Theor. Appl. Electron. Commer. Res. 2020, 15, 66-80. [CrossRef]

10. Granovetter, M.S. The strength of weak ties. Am. J. Sociol. 1973, 78, 1360-1380. [CrossRef]

11. Lin, R.; Utz, S. The emotional responses of browsing Facebook: Happiness, envy, and the role of tie strength. Comput. Hum. Behav. 2015, 52, 29-38. [CrossRef]

12. Wang, J.-C.; Chang, C.-H. How online social ties and product-related risks influence purchase intentions: A Facebook experiment. Electron. Commer. Res. Appl. 2013, 12, 337-346. [CrossRef]

13. Song, T.; Yi, C.; Huang, J. Whose recommendations do you follow? An investigation of tie strength, shopping stage, and deal scarcity. Inf. Manag. 2017, 54, 1072-1083. [CrossRef]

14. Koo, D.-M. Impact of tie strength and experience on the effectiveness of online service recommendations. Electron. Commer. Res. Appl. 2016, 15, 38-51. [CrossRef]

15. Wang, H.; Zhang, Z. How online social ties and product related factors influence purchasing intention in mobile social commerce context? Int. J. Mob. Commun. 2019, 17, 191-212. [CrossRef]

16. Samuel, L.H.S.; Balaji, M.; Wei, K.K. An Investigation of Online Shopping Experience on Trust and Behavioral Intentions. J. Internet Commer. 2015, 14, 233-254. [CrossRef]

17. Rose, S.; Hair, N.; Clark, M. Online Customer Experience: A Review of the Business-to-Consumer Online Purchase Context. Int. J. Manag. Rev. 2011, 13, 24-39. [CrossRef]

18. Chen, Y.; Lehto, X.; Choi, S. Effect of Experience on Cognition, Affect and Satisfaction: The Case of Japanese Visitors to Macau. J. Hosp. Mark. Manag. 2009, 18, 273-293. [CrossRef]

19. Liu, F.; Lim, E.T.; Li, H.; Tan, C.-W.; Cyr, D. Disentangling utilitarian and hedonic consumption behavior in online shopping: An expectation disconfirmation perspective. Inf. Manag. 2020, 57, 103199. [CrossRef]

20. Zaichkowsky, J.L. Measuring the Involvement Construct. J. Consum. Res. 1985, 12, 341. [CrossRef]

21. Lu, C.-C.; Wu, I.-L.; Hsiao, W.-H. Developing customer product loyalty through mobile advertising: Affective and cognitive perspectives. Int. J. Inf. Manag. 2019, 47, 101-111. [CrossRef]

22. Rout, T.K.; Jha, G.; Singh, A.K.; Bandyopadhyay, N.; Mohanty, O.N. Customer service experiences: Developing and applying a sequential incident laddering technique. Eur. J. Mark. 2013, 47, 738-768.

23. Hong, I.B. Understanding the consumer's online merchant selection process: The roles of product involvement, perceived risk, and trust expectation. Int. J. Inf. Manag. 2015, 35, 322-336. [CrossRef]

24. Demoulin, N.; Willems, K. Servicescape irritants and customer satisfaction: The moderating role of shopping motives and involvement. J. Bus. Res. 2019, 104, 295-306. [CrossRef]

25. Eroglu, S.A.; Machleit, K.A.; Davis, L.M. Empirical testing of a model of online store atmospherics and shopper responses. Psychol. Mark. 2003, 20, 139-150. [CrossRef]

26. Huang, E. Online experiences and virtual goods purchase intention. Internet Res. 2012, 22, 252-274. [CrossRef]

27. Zarouali, B.; Poels, K.; Walrave, M.; Ponnet, K. 'You talking to me?' The influence of peer communication on adolescents' persuasion knowledge and attitude towards social advertisements. Behav. Inf. Technol. 2018, 37, 502-516. [CrossRef]

28. Granovetter, M.S. The strength of weak ties. Soc. Netw. 1977, 78, 347-367.

29. Marsden, P.V.; Campbell, K.E. Measuring Tie Strength. Soc. Forces 1984, 63, 482. [CrossRef]

30. Lowry, P.B.; Wilson, D.W.; Haig, W.L. A Picture is Worth a Thousand Words: Source Credibility Theory Applied to Logo and Website Design for Heightened Credibility and Consumer Trust. Int. J. Hum. Comput. nteract. 2013, 30, 63-93. [CrossRef]

31. Wenzel, S.; Benkenstein, M. The influence of relationship closeness on central motives for joint shopping and satisfaction with the shopping experience among adolescents. SMR J. Serv. Manag. Res. 2019, 3, 126-136. [CrossRef]

32. Molinillo, S.; Navarro-García, A.; Anaya-Sánchez, R.; Japutra, A. The impact of affective and cognitive app experiences on loyalty towards retailers. J. Retail. Consum. Serv. 2020, 54, 101948. [CrossRef]

33. Khalifa, M.; Liu, V. Online consumer retention: Contingent effects of online shopping habit and online shopping experience. Eur. J. Inf. Syst. 2007, 16, 780-792. [CrossRef]

34. Lu, L.-C.; Chang, W.-P.; Chang, H.-H. Consumer attitudes toward blogger's sponsored recommendations and purchase intention: The effect of sponsorship type, product type, and brand awareness. Comput. Hum. Behav. 2014, 34, 258-266. [CrossRef] 
35. Hair, J.F.; Black, W.C.; Babin, B.J.; Anderson, R.E. Multivariate Data Analysis, 7th ed.; Prentice Hall: Upper Saddle River, NJ, USA, 2009.

36. Zhang, X.; Ma, L.; Xu, B.; Xu, F. How social media usage affects employees' job satisfaction and turnover intention: An empirical study in China. Inf. Manag. 2019, 56, 103136. [CrossRef]

37. Chen, W.; Fan, C.-Y.; Liu, Q.-X.; Zhou, Z.; Xie, X.-C. Passive social network site use and subjective well-being: A moderated mediation model. Comput. Hum. Behav. 2016, 64, 507-514. [CrossRef]

38. Hair, J.F.; Risher, J.J.; Sarstedt, M.; Ringle, C.M. When to use and how to report the results of PLS-SEM. Eur. Bus. Rev. 2019, 31, 2-24. [CrossRef]

39. Prebensen, N.K.; Xie, J. Efficacy of co-creation and mastering on perceived value and satisfaction in tourists' consumption. Tour. Manag. 2017, 60, 166-176. [CrossRef]

40. Keil, M.; Tan, B.C.Y.; Wei, K.-K.; Saarinen, T.; Tuunainen, V.; Wassenaar, A. A Cross-Cultural Study on Escalation of Commitment Behavior in Software Projects. MIS Q. 2000, 24, 299. [CrossRef]

41. McClure, C.; Seock, Y.-K. The role of involvement: Investigating the effect of brand's social media pages on consumer purchase intention. J. Retail. Consum. Serv. 2020, 53, 101975. [CrossRef]

42. Wen, C.; Tan, B.C.Y.; Chang, T.T. Advertising effectiveness on social network sites: An investigation of tie strength, endorser expertise and product type on consumer purchase intention. In Proceedings of the International Conference on Information Systems, Phoenix, AZ, USA, 15-18 December 2009; pp. 15-18.

43. Chen, C.C.; Chen, Y.-R.; Xin, K. Guanxi Practices and Trust in Management: A Procedural Justice Perspective. Organ. Sci. 2004, 15, 200-209. [CrossRef]

Publisher's Note: MDPI stays neutral with regard to jurisdictional claims in published maps and institutional affiliations.

(C) 2020 by the authors. Licensee MDPI, Basel, Switzerland. This article is an open access article distributed under the terms and conditions of the Creative Commons Attribution (CC BY) license (http://creativecommons.org/licenses/by/4.0/). 